перспективність запропонованих інгредієнтів, необхідно проводити подальші дослідження для їх застосування у технологіях м'ясних посічених напівфабрикатів.

\title{
Література:
}

1. Пересічний M.І., Кравченко М.Ф., Карпенко П.О. Технологія продукції громадського харчування з використанням біологічно активних добавок : монографія. Київ : КНТЕУ, 2003. 322 с.

2. Сімахіна Г.О., Науменко Р.Ю. Модифікація харчових продуктів: багатоваріантність підходів та пріоритети. Харчові технологї: Наукові праці НУХТ. 2018. Том 24, № 6. С. 112-119.

3. Манжос О.Ф., Олійник Л.Б. Оцінка технологічних властивостей різних видів борошна у м'ясних системах. Технічні науки: Науковий вісник ПУЕТ. 2018. № 1(85). С. 66-73.

4. Олійник Л.Б., Гуменюк А.О., Лазарик Г.Ю. Модифікація технологічних характеристик фаршів із м'яса птиці. Збірник наукових статей магістрів ПУЕТ. Полтава, 2019. Вип. 14. С. 75-81.

5. Антипова Л.В., Глотова И. А., Рогов И.А. Методы исследования мяса и и мясных продуктов. Москва, 2001. 576 с.

6. мясных продуктов : підручник. Москва : Колос, 2001. 576 с.

DOI https://doi.org/10.30525/978-9934-26-046-9-36

\section{ВИКОРИСТАННЯ ГІДРОЛІЗАТУ РИБНОГО КОЛАГЕНУ У ВИРОБНИЦТВІ КУЛІНАРНОЇ ПРОДУКЦІЇ}

\author{
Олійник М. I. \\ аспірантка першого року навчання \\ Одеська національна академія харчових технологій \\ Дзюба Н. А. \\ кандидат технічних наук, доцент \\ Одеська національна академія харчових технологій \\ м. Одеса, Україна
}

Важливим завданням, що стоїть перед харчовою галуззю $є$ забезпечення усіх верств населення економічно доступними та якісними продуктами харчування [1, с. 207-209]. 
Для отримання стійких харчових систем одночасно із застосуванням спеціальних технічних засобів, технологічних процесів і прийомів біотехнології застосовують речовини, що складають групу структуроутворювачів, що змінюють консистенцію харчових продуктів [2, с. $5-8]$.

В даний час ведеться активний пошук нових джерел сировини $\mathrm{i}$ способів їх переробки в якісну харчову продукцію. Перед будь-якою галуззю переробної промисловості завжди стоять завдання щодо підвищення ефективності використання сировини, скорочення відходів виробництва, розширення асортименту та підвищення якості продукції, що випускається. Особливо це стосується такого цінного, який вичерпується, але поновлюваного при правильній експлуатації сировини, як гідробіонти [3, с. 144-149].

Сучасне виробництво рибопродукції супроводжується великою кількістю білоквмісних відходів (кістки, плавники, шкіра, луска і т.д.), що становлять від 30 до 70\% від маси вихідної сировини [4, с. 55-58].

У харчовій промисловості колаген і продукти його гідролізу використовуються при виробництві желатину, для освітлення вин, для отримання харчових плівок, покриттів, їстівних оболонок як структуроутворювач - в зливках для консервів і рибних фаршів, формованих рибних виробів, при виробництві штучної ікри, бульйонів, холодців, соусів, різних оздоровчих напоїв та коктейлів та як добавка - в хлібопекарському і кондитерському виробництвах [4, с. 55-58].

Інтерес до колагену, виділеного з рибної продукції, пов'язаний з тим, що губчаста енцефалопатія стала настільки серйозною проблемою, що і використання колагену тваринного походження стає небезпечним [5]. Також відомо, що колаген гідробіонтного походження має низку переваг по відношенню до тваринних білків. Найбільшу цінність мають білковий гідролізат рибного колагену, так як $є$ гіпоалергенним, тому що на 96\% ідентичний людському білку [6, с. 525-534, 7, с. 456]. У 10 грамах колагену знаходиться 9,4 г білка, 10 мг натрію i невелику кількість кальцію, калію, заліза.

В даний час інтерес до відходів рибопереробного виробництва (глюкозамін, хондроїтин, поліненасичені жирні кислоти, фосфоліпіди, біокальцій, фосфор і т.д.) як до джерела цінних біологічно активних речовин не слабшає. Крім того, вторинні рибні ресурси виступають цінною сировиною для отримання різних лікувальних і стимулюючих препаратів, тому що містять численні біоактивні компоненти, які мають імуноактивну властивість, здатність нормалізувати кров'яний тиск, активізувати процеси травлення. Основним напрямом переробки 
вторинної рибної сировини $є$ отримання з них біологічно цінних компонентів, фізіологічна роль обумовлена їх здатністю впливати на обмінні процеси, брати участь у формуванні тканин організму людини, надавати профілактичну дію, виступати в якості загальнозміцнюючих засобів [8, с. 129-136].

Як джерело рибного колагену широко використовується шкіра морських і прісноводних риб, луска риб, хребетна кістка, плавники. Видається перспективним використання в складі молочних продуктів для відновлення хрящової і сполучної тканини, нормалізації мікрофлори і в той же час для надання необхідної структури продукту [9, с. 243-274]. Луска є структурно складною багатокомпонентною системою, що складається в основному з мінеральних речовин і колагену, може служити сировиною для отримання як харчового, так $\mathrm{i}$ технічного іхтіожелатіна, а відходи від його отримання раціонально використовувати в якості мінеральної добавки [10, с. 130-136].

Таким чином, отримання структуроутворювачів з рибної сировини $\epsilon$ досить важливим завданням. У зв'язку з цим необхідно розробляти науково обгрунтовані і економічно прийнятні способи переробки колагеновмісної рибної сировини.

\section{Література:}

1. Поварова Н.М, Журба Н.О. Білкові добавки тваринного походження та передумови їх створення. VIII Міжнародна науковотехнічна конферениія «Наукові проблеми харчових технологій та промислової біотехнологї̈ в контексті євроінтеграції», НУХТ. 2009. C. 207-209.

2. Гранатова В.П., Запорожский А.А., Касьянов Г.И. Теория и практика получения и применения натуральных структурообразователей. Известия вузов. Пищевая технология. 2007. № 2. С. 5-8.

3. Цибизова М. Е., Язенкова Д. С., Акимова А. Ю. Ферментация костной ткани рыбного сырья как один из этапов получения структурообразователей. Вестник АГТУ. Сер.: Рыюное хозяйство. 2010. № 2. C. 144-149.

4. Воробьев В.И. Использование рыбного коллагена и продуктов его гидролиза. Известия КГТУ. 2008. № 13. С. 55-58.

5. Кушнір Н.А. Основи технології отримання колагену з рибної колагеновмісної сировини. Прогресивні техніка та технології харчових виробництв ресторанного господарства $і$ торгівлі. 2014. № 1. C. 107-116. 
6. Неклюдов А. Д., Иванкин А. Н., Бердутина А. В. Свойства и применение белковых гидролизатов. Прикладная биохимия и микробиология. Т. 35. 2000. № 5. С. 525-534.

7. Якубке Х. Д., Ешкайт Х., Запеваловой Н. П., Максимова Е. Е., Митина Ю. В. Аминокислоты, пептиды, белки. X.- M. :Мup. 1985. $456 \mathrm{c}$.

8. Самойлова Д.А., Цибизова М.Е. Вторичные ресурсы рыбной промышленности как источник пищевых и биологически активных добавок. Вестник АГТУ. Сер.: Рыбное хозяйство. 2015. № 2. C. $129-136$.

9. Титов Е.И., Ионова И.И., Краснова И.С., Волокитина З.В., Козлов Н.С. Структурно-механические показатели кисломолочных продуктов с гидролизатом белка из кожи рыб. Технологии пищевых продуктов. Вопросы питания.Приложение. 2018. Том 87, № 5. C. 243-244.

10. Якубова О. С., Котенко А. Л. Чешуя как источник получения ихтиожелатина Вестник Астраханского государственного техни-ческого у университета. Сер. Рыбное хозяйство. 2004. № 4. C. 130-136. 